\title{
The Effects of Empowerment, Training, and Teamwork on Employee Job Satisfaction: Case of the Agricultural Manufacturing Sector in Khyber Pakhtunkhwa Province, Pakistan
}

\author{
Amjad Ali \\ College of Management \\ Fujian Agriculture and Forestry University \\ Fuzhou, Fujian-350002, China \\ amjad_jamy81@yahoo.com \\ Zulfiqar Ali \\ College of Management \\ Fujian Agriculture and Forestry University \\ Fuzhou, Fujian-350002, China \\ zulfiqar3344@yahoo.com
}

\author{
Huang JianPing \\ College of Management \\ Fujian Agriculture and Forestry University \\ Fuzhou, Fujian-350002, China \\ nine_01@126.com \\ Li ZhongBin* \\ College of Management \\ Fujian Agriculture and Forestry University \\ Fuzhou, Fujian-350002, China \\ *Corresponding author: lzb15592@yahoo.com
}

\begin{abstract}
Human resources are an important source of growth for organizations. To ensure optimal utilization of human resources, it is vital to align the abilities, knowledge, and skills of the employees with appropriate roles within the organization. This study investigates the effects of three elements-employee empowerment, employee training, and teamwork-on job satisfaction in the agricultural manufacturing industry of the Khyber Pakhtunkhwa Province, Pakistan. The study was conducted in a quantitative research paradigm and was designed using a cross-sectional survey, through structured questionnaires. SPSS and structural equation modeling were used to analyze data from 315 employees. The results show that employee empowerment has a significant positive impact on job satisfaction. The impact of employee training on job satisfaction was also found to be positive and significant. Additionally, the study found that teamwork had a significant positive influence on job satisfaction. These findings could provide beneficial suggestions for management in the agricultural manufacturing industry, with emphasis on employee empowerment, training, and teamwork to improve employee job satisfaction.
\end{abstract}

Keywords-Human resources; Employee empowerment; Employee training; Teamwork; Job satisfaction

\section{INTRODUCTION}

Job satisfaction is an essential part of an employee's work and life experience. Its importance is linked to the employee receiving internal and external rewards that encourage them to remain in the workplace and continue to spend a significant amount of time performing their duties. Currently, most organizations understand that employees are their most important resource. However, for these resources to function at their greatest capacity, it is necessary to continually examine their work satisfaction in the organization and continually motivate them to achieve organizational goals. Job satisfaction can be viewed as a key factor that may affect the success of various workplaces. For example, high levels of job satisfaction are connected with improved performance [1] and organizational commitment [2]. However, job dissatisfaction is associated with problems such as absenteeism, delays, strikes, turnover intentions, and employee turnover [3]. Therefore, job satisfaction is a key tool that leads to positive working attitudes. Particularly, satisfied employees may be more creative, loyal, flexible, and innovative [4]. Therefore, organizations should invest in activities or programs that promote employee job satisfaction. It is believed that through a higher level of job satisfaction, the performance of the organization can continually improve.

The concept of job satisfaction has been extensively studied by many experts, managers, and researchers who believe that their trends can influence and affect work productivity, employee retention, and employee turnover. There are many significant contributions through studies on this topic. Additionally, job satisfaction is one of the key factors that affect organizational success, and it is necessary to monitor it to avoid negative impact on organizational performance [5]. Specifically, the motivation and satisfaction of effective employee work is important for the organization to remain competitive. Job satisfaction can be measured based on job characteristics and employees' perceptions of their work. Satisfied employees tend to display a positive attitude in their work, and may be more effective. According to Jessen [6], when employees are satisfied with their work, they become more productive, stable, loyal, and committed to the organization. Job satisfaction leads to increased productivity of the individual, people are committed to the organization, the physical and mental health of the person will be assured, and 
the spirit of the person will rise, all of which will enable people to achieve their life goals faster and learn new work skills.

The purpose of this research is to investigate the impact of employee empowerment, training, and teamwork on job satisfaction in Pakistan's agricultural manufacturing industry. Conducting a literature review on this topic, most previous studies were conducted in Western countries, with only a few researchers focusing on agricultural manufacturing in Pakistan. In view of this, the purpose of this research is to undertake an empirical analysis on the correlation among the study variables and to contribute to the body of knowledge with actionable recommendations. The following sections begin with a review of the literature, followed by methodology, results, and finally, the discussion and conclusions.

\section{LITERATURE REVIEW}

\section{A. Job Satisfaction}

There is a large amount of literature on employee job satisfaction resulting in several definitions. Locke [7] first defined employee job satisfaction as an enjoyable or positive emotional state resulting from an assessment of work or work experience. In contrast to the humanitarian view that the degree of job satisfaction reflects the treatment of workers, the utilitarian view is that job satisfaction is the antecedent of positive organizational functioning. Therefore, the utilitarian view of job satisfaction emphasizes the positive association between job satisfaction and advanced organizational performance [8]. If an employee is satisfy at work, they are less likely to quit, which decreases turnover. Even though the ideas behind job satisfaction are underscored by the acceptance that employees who are well satisfied tend to perform at greater levels, however, there is no agreement establishing a causal association between job satisfaction and performance. In other words, whether job satisfaction causes productivity or productivity causes job satisfaction remains to be determined [9].

Job satisfaction is the core of an employee's work life, and the effective use of people within the organization. Seeking an understanding of the causes of job satisfaction, and/or dissatisfaction, is a continuing area of interest to managers and social scientists. The basis of this is that, satisfied employees preferably stay with the organization for a long period of time and thus increasing their productivity and efficiency levels. Conversely, dissatisfied employees are prone to frustration and more liable to leave the organization with less productivity levels. Herzberg, Mausner and Snyderman [10] contribute to the main theories of job satisfaction by dividing the needs of the employees into two categories, namely, hygiene factors and motivation factors. Hygiene factors do not cause satisfaction; however, they can turn "dissatisfaction" into "no dissatisfaction" or "short-term motivation," whereas motivational factors have long lasting effects, as they nurture positive attitude toward the work and change no dissatisfaction into satisfaction. Hygiene factors satisfy the employees in certain conditions, such as interpersonal relations, physical working conditions, supervision, salary, benefits. However, it has been mentioned that these factors do not fully satisfy the employees, and that they only reduce the dissatisfaction level [11].

\section{B. Employee Empowerment}

Organizations should provide opportunities for employees to develop their aptitudes and knowledge to accomplish longterm objectives and ensure mutual benefits. Employee empowerment is a motivational strategy created to improve performance by optimizing opportunities for involvement and participation in decision-making. It is mainly concerned with participating in decision-making, developing trust, motivation, and eliminating any restrictions between top management and employee [12]. Employee empowerment occurs when employees share their information, improve their intellectual capacity to gain autonomy, and make decisions. It is considered important to increasing the behavioral elements of individual's, in order to accomplish a higher level of innovation, selfdetermination, entrepreneurship, independent thinking, support, and teamwork [13]. Employee empowerment is an effective strategy that an organization uses to improve the responsibilities and competencies of its employees. It is believed that if employees are empowered, they will perform their tasks more effectively.

Employee empowerment has been widely accepted as an important contributor to organizational achievement, and many authors have seen this importance on the direct impact on employee job satisfaction, organizational commitment, and employee performance. Prior studies have found that empowerment has a positive impact on job satisfaction [12, 13] Employee empowerment emphasizes that the contribution of employees in an organization is highly valued and can improve job satisfaction and organizational commitment. Ripley and Ripley [14] argue that empowerment can lead to positive organizational outcomes such as increasing employee job motivation and responsibilities, improving employee loyalty and improving service quality, reducing turnover intention, and maximizing productivity. Several behavioral outcomes emerge from empowering practices such as higher job satisfaction, increased job involvement, and enhanced organizational commitment. Kirkman and Rosen [15] confirm that empowered employees who are given greater autonomy to make decisions are generally more satisfied with their work and tend to commit to their team members and organizations. Thus, based on this discussion, the following hypotheses are proposed:

Hypothesis 1. Employee empowerment is positively related to job satisfaction.

\section{Employee Training}

Training is an indispensable activity in managing the human resources in any organization. The fundamental principles of training rest on the need for employees to produce meaningful work through learning programs supported by scientific theories, taking into account the elements of effectiveness, efficiency, and personal differences [16]. Training as an organized process modifying the proficiencies of employees to enable them to achieve their goals. Organizations that provide training to employees show a high degree of commitment to their organizations. Additionally, it 
was suggested that employee training programs help them update their skills and knowledge, and contribute to devotion and job satisfaction [17]. Low levels of employee training have resulted in a high level of employee turnover, and sufficient training has a positive impact on employee retention [18]. For training to achieve its objectives, it has to be planned and organized in an orderly way to increase the level of knowledge, competencies, skills, and that are necessary to ensure effective performance. Traditionally, most organizations did not see the value of training and believed that it was expensive and not worth the investment. However, the situation is changing. On a global scale, organizations are recognizing the importance of modern training methods.

Training is regarded as an important variable that can influence the behaviors of employees. A number of scholars found that training had a positive impact on job satisfaction [19-21]. According to [22], the training program aims to improve employee performance through the use of shared knowledge, skills, and competencies, providing greater benefits to employees and the organization itself. Adesola, Oyeniyi and Adeyemi [23] have also demonstrated that training employees can lead to favorable job satisfaction and organizational commitment. Other scholars such as Tarasco and Damato [24] describe training as continuing professional development and that it plays an essential role in building job satisfaction. Based on the above discussion, studies have shown that some scholars provide evidence of positive associations between employee training and job satisfaction, and therefore, the following hypothesis is proposed:

Hypothesis 2. Employee training is positively related to job satisfaction.

\section{Teamwork}

Today, many organizations have a system that encourages people to work together in unity to enhance productivity and efficiency. Getting people together has always been an effective strategy for the achievement of organizational aims, goals thereby maximizing the different interests of individuals for the common good. This enhances the principle of Espirit de-corps (Team work) [25]. Today, senior level employees such as managers in most organizations have developed the idea of making their subordinates work in teams. This strategy has resulted in making employees realized their talents and professionalism for the general good of the organization [26]. Similarly, Jones, Richard, Paul, Sloane and Peter [27] suggest that employees who work with others on a team may be more efficient and productive than others. The authors point out that teams in an organization are often made up of people who have acquired the basic knowledge and skills that are important to achieving the desired goals. Ultimately, team spirit can enhance all members of the team to pass on necessary skills for the execution of assignments.

Previous research has found that teamwork has a positive impact on job satisfaction [28]. Some scholars have also provided evidence that greater levels of teamwork are associated with improved employee satisfaction, prompting them to work harder [29, 30]. Musriha [31] reported that effective teamwork can improve job satisfaction. Therefore, teamwork among the members of the organization is necessary for employee's job satisfaction, which will directly affect the organization's performance. In addition, effective teamwork can motivate the organization's employees to improve performance and self-efficiency. Based on the above discussion, studies have shown that some scholars provide evidence of positive associations between teamwork and job satisfaction, and therefore, the following hypothesis is proposed:

Hypothesis 3. Teamwork is positively related to job satisfaction.

\section{METHOD}

The population of this study included employees of the agricultural manufacturing industry of the Khyber Pakhtunkhwa Province, Pakistan. In this research, a crosssectional survey design was used. Survey questionnaires, adopted from multiple studies and consisting of 25 items to measure perceptual constructs, along with some demographic information, were used for data collection. The convenient sampling method was utilized to collect data. For this study, a survey was conducted using the questionnaire technique in two major cities of the Khyber Pakhtunkhwa Province, Peshawar, and Mardan. A total of 400 questionnaires were distributed in 13 agricultural manufacturing firms and 315 questionnaires were returned. Thus, the overall response rate was $79 \%$. The target populations of this survey were employees working in production, marketing, human resources, accounting \& finance, and R\&D departments of 13 agricultural manufacturing industries. Quantitative methods are the most appropriate strategies for understanding the direct and indirect relationships between multiple factors and examining how they can influence each other. The collected data was analyzed by using SPSS and the structural equation modeling on AMOS.

\section{A. Demographic Information}

Of the 315 respondents, $84.1 \%$ were male, while the remaining $15.9 \%$ were female. This shows that most employees in the agricultural manufacturing industry are male. Of the age categories, $56.5 \%$ of the respondents were between 21 and 30 years, followed by 31 to 40 years (37.1\%). The smallest group was those from 41 to 50 years old (6.3\%). In education, $4.4 \%$ of the respondents had an M.Phil. degree, $32.7 \%$ a graduate degree, $38.1 \%$ a bachelor's degree, $18.7 \%$ a high school certificate, and $6.0 \%$ a diploma or lower. Based on the respondents' job tenure information, only $16.5 \%$ worked in the current organization for more than 7 years, $23.5 \%$ worked for 4 to 7 years, $43.2 \%$ worked for 1 to 3 years, while the remaining $16.8 \%$ had less than 1 year of work experience. See Table 1 for more details variables. 
TABLE I. DEMOGRAPHIC VARIABLES

\begin{tabular}{|c|c|c|c|}
\hline Variable labels & Value labels & Frequency & Valid (\%) \\
\hline \multirow{2}{*}{ Gender } & Male & 265 & 84.1 \\
\hline & Female & 50 & 15.9 \\
\hline \multirow{3}{*}{ Age } & 21-30 years & 178 & 56.5 \\
\hline & $31-40$ years & 117 & 37.1 \\
\hline & $41-50$ years & 20 & 6.3 \\
\hline \multirow{5}{*}{ Qualification } & M.Phil. & 14 & 4.4 \\
\hline & Graduate & 103 & 32.7 \\
\hline & Bachelor & 120 & 38.1 \\
\hline & High School & 59 & 18.7 \\
\hline & Diploma & 19 & 6.0 \\
\hline \multirow{4}{*}{ Experience } & Less than 1 year & 53 & 16.8 \\
\hline & 1-3 year & 136 & 43.2 \\
\hline & 4-7 year & 74 & 23.5 \\
\hline & Above 7 year & 52 & 16.5 \\
\hline Total participants & & 315 & 100 \\
\hline
\end{tabular}

\section{B. Instruments and Procedures}

In designing the questionnaire, multiple items adopted from previous studies were used to measure the perceptual constructs, i.e. employee empowerment, teamwork, training, and job satisfaction. To carry out the survey, two management scholars were asked to review the survey questionnaire and provide feedback. The questionnaire was modified per their feedback. The selection of the measurement scale mentioned below refers to the satisfactory value of Cronbach's alpha, providing reliability evidence. For example, five items were adapted from the study of Men [32] to measure employee empowerment. These five items asked about the autonomy and authority that employees receive from their management. To measure employee training, six items were adapted from the study of Schmidt [33]. Additionally, six items were adapted from the studies of Shanahan, Best, Finch and Sutton [34] to measure teamwork. Finally, four items were adapted from the studies of [35] to measure job satisfaction. Respondents were asked to rank their opinions about the questionnaire items based on a five-point Likert scale that ranges from (1= strongly disagree to $5=$ strongly agree).

\section{Reliability Analysis}

Cronbach's alpha was used to examine the reliability of the developed instrument. As shown in Table 2, the Cronbach's alpha values for all variables ranged from 0.859 to 0.912 , which achieved a coefficient alpha above the minimum acceptable level 0.7. Far above the cut-off line of reliability as recommended by Hair, Sarstedt, Ringle and Mena [36] and Sekaran and Bougie [37]. The independent variable of employee training has the highest Cronbach's alpha of 0.912 (6 items), followed by teamwork with a Cronbach's alpha of 0.909 (6 items). Both variables have a value more than 0.9, which are excellent. The other dependent variable of employee job satisfaction and the independent variable of employee empowerment have a Cronbach's alpha of 0.885 (4 items) and 0.859 (5 items) respectively, which is good. Finally, the reliability of the scales used in this study was high, with a Cronbach's alpha value close to 1.0.

TABLE II. RELIABILITY ANALYSIS

\begin{tabular}{|l|c|c|c|}
\hline \multicolumn{1}{|c|}{ Variables } & $\begin{array}{c}\text { Number of } \\
\text { Items }\end{array}$ & $\begin{array}{c}\text { Total } \\
\text { Number }\end{array}$ & $\begin{array}{c}\text { Cronbach's } \\
\text { Alpha Value }\end{array}$ \\
\hline Employee Empowerment & 5 & 315 & 0.859 \\
\hline Employee Training & 6 & 315 & 0.912 \\
\hline Teamwork & 6 & 315 & 0.909 \\
\hline Job Satisfaction & 4 & 315 & 0.885 \\
\hline $\begin{array}{l}\text { All variables (Final } \\
\text { Measurement Model) }\end{array}$ & 21 & 315 & 0.946 \\
\hline
\end{tabular}

\section{Composite Reliability}

Table 3 shows the composite reliability, which was calculated using Microsoft Excel to ensure the reliability of all constructs. Overall, the value of the composite reliability is found to be acceptable (greater than 0.70), indicating its internal consistency and unidimensionality to corresponding constructs, respectively. By observing these results, it can be said that the reliability assumption is satisfied, since all values exceed the recommended threshold of 0.70 recommended by Hair, Black, Babin, Anderson and Tatham [38]. Therefore, reliability assumptions are met.

\section{TABLE III. COMPOSITE RELIABILITY}

\begin{tabular}{|l|c|}
\hline \multicolumn{1}{|c|}{ Constructs } & $\begin{array}{c}\text { CR }=\text { (sum of standardized loading) }{ }^{2} /(\text { sum of } \\
\text { standardized loading) } \\
\text { measurement error })\end{array}$ \\
\hline $\begin{array}{l}\text { Employee } \\
\text { Empowerment }\end{array}$ & $\mathrm{CR}=(3.71)^{\wedge} 2 /\left((3.71)^{\wedge} 2+2.3\right)=0.86$ \\
\hline $\begin{array}{l}\text { Employee } \\
\text { Training }\end{array}$ & $\mathrm{CR}=(4.80)^{\wedge} 2 /\left((4.80)^{\wedge} 2+2.16\right)=0.91$ \\
\hline Teamwork & $\mathrm{CR}=(4.73)^{\wedge} 2 /\left((4.73)^{\wedge} 2+2.27\right)=0.91$ \\
\hline Job Satisfaction & $\mathrm{CR}=(3.26)^{\wedge} 2 /\left((3.26)^{\wedge} 2+1.33\right)=0.89$ \\
\hline
\end{tabular}

\section{CORRELATION ANALYSIS}

The Spearman's correlation coefficients (r) were conducted to determine the relationship among the four variables (i.e. job satisfaction, employee empowerment, employee training, and teamwork). Table 4 illustrates the correlation analysis.

According to the results of the study, there was a strong positive correlation between employee empowerment and employee job satisfaction $(r=0.625, p<0.01)$. Employee training was also positively correlated with job satisfaction ( $\mathrm{r}=$ 0.613, $\mathrm{p}<0.01$ ). Additionally, teamwork also revealed a strong positive correlation with job satisfaction $(r=0.550, \mathrm{p}<0.01)$. 
TABLE IV. CORRELATION ANALYSIS-EMPLOYEE EMPOWERMENT, EMPLOYEE TRAINING, TEAMWORK AND JOB SATISFACTION

\begin{tabular}{|l|l|l|l|l|l|}
\hline \multicolumn{1}{|c|}{ Variables } & & EE & ET & TW & \multicolumn{1}{c|}{ JS } \\
\hline \multirow{2}{*}{ Employee Empowerment } & Pearson Correlation & 1 & $.589 * *$ & $.661^{* *}$ & $.625^{* *}$ \\
\cline { 2 - 7 } & Sig. (2-tailed) & & .000 & .000 & .000 \\
\hline \multirow{2}{*}{ Employee Training } & Pearson Correlation & $.589 * *$ & 1 & $.560^{* *}$ & $.613^{* *}$ \\
\cline { 2 - 7 } & Sig. (2-tailed) & .000 & & .000 & .000 \\
\hline \multirow{2}{*}{ Teamwork } & Pearson Correlation & $.661^{* *}$ & $.560^{* *}$ & 1 & $.550^{* *}$ \\
\cline { 2 - 7 } & Sig. (2-tailed) & .000 & .000 & & .000 \\
\hline \multirow{2}{*}{ Job Satisfaction } & Pearson Correlation & $.625^{* *}$ & $.613^{* *}$ & $.550^{* *}$ & 1 \\
\cline { 2 - 6 } & Sig. (2-tailed) & .000 & .000 & .000 & \\
\hline \multirow{2}{*}{$* *$ Correlation is significant at the 0.01 level (2-tailed). N=315 } & \\
\hline
\end{tabular}

\section{MEASUREMEnT Model}

Confirmatory factor analysis (CFA) was adopted to measure construct validity. The full measurement model included four latent constructs (employee empowerment, employee training, teamwork, and job satisfaction) and 21 observed variables. It is important to conduct CFA to ensure that the correct items within a construct are being measured and not the items of other constructs. Additionally, CFA can support the convergent validity assumptions and allow for handling of any multicollinearity problems. Since all instruments were adapted from different studies, CFA was used instead of exploratory factor analysis. The CFA was conducted using the SEM (structural equation modeling) on AMOS 21 through the measurement model, which included all items. Overall, the findings of the study showed that the CFA was successful, as the factor loadings values of all 21 items were ranged between 0.65 and 0.88 . Additionally, the standardized factor loadings for all items are greater than the absolute threshold of 0.50 , as recommended by Hair, Black, Babin, Anderson and Tatham [38]. Table 5 contains factor loading.
TABLE V. MEASUREMENT SCALE OF FINAL ITEM

\begin{tabular}{|c|c|c|}
\hline Code & Construct/Item & $\begin{array}{r}\text { Factor } \\
\text { Loading }\end{array}$ \\
\hline & EMPLOYEE EMPOWERMENT & \\
\hline EE1 & $\begin{array}{l}\text { I got adequate equipment and help to get the job } \\
\text { carried out }\end{array}$ & 0.72 \\
\hline EE2 & $\begin{array}{l}\text { I am provided with ample information to get the } \\
\text { job done }\end{array}$ & 0.83 \\
\hline EE3 & $\begin{array}{l}\text { I am charged with the authority to create relevant } \\
\text { decisions to perform my job well }\end{array}$ & 0.74 \\
\hline EE4 & $\begin{array}{l}\text { My supervisor reposes confidence in me to come } \\
\text { with the right decisions in my job }\end{array}$ & 0.77 \\
\hline \multirow[t]{2}{*}{ EE5 } & $\begin{array}{l}\text { I have freedom and considerable opportunity for } \\
\text { interdependence in how I do my job }\end{array}$ & 0.65 \\
\hline & EMPLOYEE TRAINING & \\
\hline ET1 & $\begin{array}{l}\text { My department organizes staff development } \\
\text { seminars to respond to the changing needs of the } \\
\text { work place }\end{array}$ & 0.78 \\
\hline ET2 & $\begin{array}{l}\text { In my department training and development are } \\
\text { encouraged and rewarded }\end{array}$ & 0.8 \\
\hline ET3 & $\begin{array}{l}\text { The employment training packages I got well } \\
\text { suited my job }\end{array}$ & 0.83 \\
\hline ET4 & $\begin{array}{l}\text { The trainings I receive on the job help me to meet } \\
\text { my general needs }\end{array}$ & 0.83 \\
\hline ET5 & The training program fulfilled my expectations & 0.8 \\
\hline \multirow[t]{2}{*}{ ET6 } & $\begin{array}{l}\text { I feel accomplished and satisfied with the number } \\
\text { of training I got on my employment. }\end{array}$ & 0.76 \\
\hline & \begin{tabular}{|c|} 
TEAMWORK \\
\end{tabular} & \\
\hline TW1 & The team members feel very close to each other & 0.74 \\
\hline TW2 & $\begin{array}{l}\text { The team members share equal respect for each } \\
\text { other }\end{array}$ & 0.82 \\
\hline TW3 & $\begin{array}{l}\text { The members of my department always work as a } \\
\text { team to get the job done }\end{array}$ & 0.79 \\
\hline TW4 & The members of my team work well together & 0.8 \\
\hline TW5 & My team members work hard to get things done & 0.81 \\
\hline \multirow[t]{2}{*}{ TW6 } & $\begin{array}{l}\text { My team members encourage each other to } \\
\text { succeed when carrying out the job }\end{array}$ & 0.77 \\
\hline & JOB SATISFACTION & \\
\hline JS1 & $\begin{array}{l}\text { Currently, I am satisfied with the kind of work I } \\
\text { am doing }\end{array}$ & 0.85 \\
\hline JS2 & I am satisfied with my current job earning & 0.71 \\
\hline JS3 & $\begin{array}{l}\text { I am extremely glad that I chose this organization } \\
\text { over others }\end{array}$ & 0.82 \\
\hline JS4 & Overall, I am satisfied with my current job & 0.88 \\
\hline
\end{tabular}

\section{AVERAGE VARIANCE EXTRACTED}

Table 6 shows the average variance extracted (AVE), the AVE was calculated using Microsoft Excel. The AVE of each construct was greater than the minimum cut-off point of 0.5 .

TABLE VI. AVERAGE VARIANCE EXTRACTED

\begin{tabular}{|l|l|}
\hline \multicolumn{1}{|c|}{ Constructs } & \multicolumn{1}{|c|}{$\begin{array}{c}\text { AVE= (sum of squared } \\
\text { standardized loading) } / \text { (sum of } \\
\text { squared standardized loading }+ \\
\text { sum of indicator measurement } \\
\text { error) }\end{array}$} \\
\hline Employee Empowerment & $\mathrm{AVE}=2.77 /(2.77+2.23)=0.55$ \\
\hline Employee Training & $\mathrm{AVE}=3.84 /(3.84+2.16)=0.64$ \\
\hline Teamwork & $\mathrm{AVE}=3.73 /(3.73+2.27)=0.62$ \\
\hline Job Satisfaction & $\mathrm{AVE}=2.67 /(2.67+1.33)=0.67$ \\
\hline
\end{tabular}




\section{STRUCTURAL MODEL}

In the measurement model, after obtaining satisfactory CFA results, the succeeding step is to draw the structural model and confirm that it has acceptable data fitting. As can be seen from Figure 1 below, the structural model fully fits the data, as the values of $\left(X^{2}=409.296, d f=183, X^{2} / d f=2.237\right.$, RMSEA $=$ $0.063, A G F I=0.855, G F I=0.885, T L I=0.941$, and $C F I=$ 0.949). For GFI and AGFI, values more than 0.8 are acceptable for model fitting [39]. TLI and CFI also need to have a value greater than 0.9. Additionally, RMSEA is below 0.08 and CIMIN is less than 3, which shows acceptable model fit [40]. However, since the p-value needs to be greater than 0.05 , depending on the sample size and number of parameters indicated in the model, and in many cases it may not be able to achieve the desired level [38]. Thus, good values for other indicators can show good model fit [38].

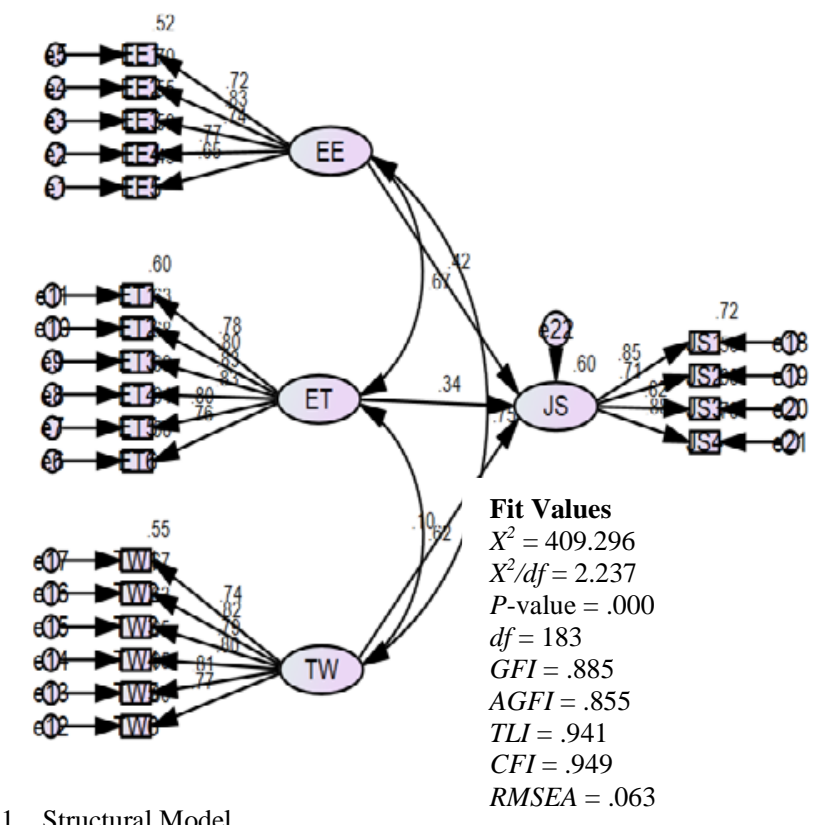

Fig. 1. Structural Model

\section{HYPOTHESIS TESTING}

The regression results were obtained from the output of the structural model, to examine the hypotheses of this study. The results are shown in Table 7 , according to the results of the study, which revealed that employee empowerment has significant impact on employee job satisfaction $(\beta=0.525$, tvalue $=4.634, \mathrm{p}<0.05)$. Meaning employee empowerment contributes more than $52 \%$ to employee job satisfaction. Results of the present study confirm hypothesis 1 . The regression results of the study also confirm that employee training has significant positive impact on employee job satisfaction $(\beta=0.347$, $t$-value $=5.067, \mathrm{p}<0.05)$. According to these results, employee-training programs contribute to employee job satisfaction almost 35\%. This result of the study authenticates hypothesis 2. Lastly, the regression results also showed that teamwork has significant impact on job satisfaction $(\beta=0.117, \mathrm{t}$-value $=1.296, \mathrm{p}<0.05)$. Based on these results, teamwork contributes to employee job satisfaction almost $12 \%$. This result of the study validates hypothesis 3. Overall, these factors explain $60 \%$ proportion of variation in employee job satisfaction.

TABLE VII. REGRESSION WEIGHT

\begin{tabular}{|c|c|c|c|c|c|c|}
\hline $\begin{array}{c}\text { Hypothesi } \\
\text { s }\end{array}$ & $\begin{array}{c}\text { Hypothesized } \\
\text { Effect }\end{array}$ & $\begin{array}{c}\text { Std. } \\
\text { Estimate }\end{array}$ & S.E. & C.R. & $\mathbf{P}$ & Label \\
\hline H1 & $\mathrm{JS} \leftarrow \mathrm{EE}$ & 0.525 & 0.113 & 4.634 & $* * *$ & Yes \\
\hline $\mathrm{H} 2$ & $\mathrm{JS} \leftarrow \mathrm{ET}$ & 0.347 & 0.068 & 5.067 & $* * *$ & Yes \\
\hline H3 & $\mathrm{JS} \leftarrow \mathrm{TW}$ & 0.117 & 0.09 & 1.296 & 0.012 & Yes \\
\hline
\end{tabular}

IX. DISCUSSION

The purpose of this research was to investigate the impacts of employee empowerment, employee training, and teamwork on job satisfaction. To achieve this objective, data was gathered from employees in the agricultural manufacturing industry in the Khyber Pakhtunkhwa Province, Pakistan. Prior research has consistently found a positive influence of empowerment on job satisfaction; this study's result is consistent with previous research. This observation reinforces the previous findings on empowerment effects, such as the findings of [41-43]. If organizations empower employees, they can enjoy employee loyalty to the organization and work through job satisfaction. Employees who perceive that they are empowered are more likely to be satisfied with their works, and satisfied workers are more likely to stay in the organization. Moreover, it is suggested that a nurturing environment for improving the concept of empowerment will have a positive influence on the employees, and ultimately improve the effectiveness of the organization. Therefore, encouraging employees to feel authorized and responsible to make decisions that are within their capacities should be considered as part of the organizational culture and work environment. The study suggests that strategies to improve job empowerment can improve job satisfaction.

Most prior studies have also shown that the empowerment of employees can improve job satisfaction, work effectiveness, and minimized work-related stress. The purpose of empowerment is to build a culture where workers can freely express themselves and have the authority to make decisions about their own work. Participative management, or empowerment, is one of the most effective ways to help employees use their creativity to improve their performance within the organization. This study suggests that organizations contemplating employee turnover need to boost employee job satisfaction. Managers who want to effectively design empowerment programs to minimize rate of turnover, must tailor programs comprehensively to target the employees' job satisfaction.

This study found that employee training had a significant positive impact on employee job satisfaction and was supported by prior research [44-46]. Training is viewed as an important element and investment by the organization, it is not only about making the organization achieve its return on investment but also creates a platform for the achievement of the competitive advantage of that organization, inherent in its productive employees. We observed that the company's productivity, service quality, employee morale, and satisfaction were improved through training. Human resources departments 
should emphasize the importance of training programs to the success of its company. If employees are well trained, their work will be more efficient. Moreover, Gazioglu and Tansel [47] confirmed a positive significant link between training and job satisfaction. The results also show that the organizations mainly want to retain employees, they consider valuable, that is, those who have the necessary skills and competencies. It is therefore very important for employees to take advantage of the training and development opportunities that are available at the organization and equip themselves with the skills they need. With regard to layoffs and retrenchments, these valuable employees may be retained by the organization. These results also provide important recommendations for policymakers to continue to focus on training programs, especially for new employees, to improve their knowledge and understanding of how to effectively complete work. This experience will improve their motivation and level of satisfaction.

Finally, the results also support our third hypothesis that teamwork had a significant positive impact on employee job satisfaction. This finding was supported by a number of researchers $[28,29]$ who found teamwork to play an important role in improving employee job satisfaction. Van Dick, Christ, Stellmacher, Wagner, Ahlswede, Grubba, Hauptmeier, Hoehfeld, Moltzen and Tissington [48] affirm that persons who are identified with their working group will conscientiously see their working situations and conditions in a positive manner, culminating into higher job satisfaction. In the manufacturing industry, joint effort is a common practice among the members of the working group, which leads to the positive feelings of the employees. Good team spirit reflects the attitude of individuals, such as commitment, self-management skills, competency, and accountability, which, in turn, demonstrate something enjoyable. They tend to have a desire to pursue satisfaction, and to react and interact with others in an interesting way. Managers are dedicated to enhancing the performance of their employees by maximizing teamwork for efficiency. They also go ahead to encourage performance at individual level to foster specialization. Nonetheless, achieving this success requires the careful planning and supervision to determine the number and kind of teamwork needed for organizational excellence. In an organization, teamwork activity is very useful which directly affects employee performance. When employees acquire enough opportunities for teamwork, their performance inevitably improves and, consequently, they will be satisfied with the work. It ensures better use of skills and may reduce the tendency of an employee to quit. Musriha [31] found that teamwork had a significant influence on job satisfaction. This means that teamwork is one of the key components of employee job satisfaction. As a result, when employees are satisfied with their work, the level of commitment to the organization will increase. Moreover, most studies have concluded that, teamwork activities could yield positive effect on job satisfaction, by providing benefits to contribute to higher organizational performance, higher productivity, competitive advantage, and improved product quantity and quality. The findings of this study suggest that efforts to increase teamwork in these environments would have a positive influence on employee job satisfaction. If employees are not satisfied, like personnel in general, they are bound to quit their jobs or have lower levels of efficiency.

\section{LiMITATION}

Future research would focus on the limitations of this study. This is a cross-sectional study in which all data was gathered at a specific time, so variables and analysis are limited to that time. Therefore, future research may focus on longitudinal data, making the results more powerful. Additionally, the study is limited to Pakistan's agricultural manufacturing industry, and further research may focus on other areas and other geographic locations in Pakistan. Finally, this study considers only three human resource practices (empowerment, training, and teamwork). Future research can consider other aspects of human resource practices, including selection and recruitment, human development, job security, and career or promotion opportunities.

\section{CONCLUSION}

An interesting finding of this study is that, employee empowerment, training, and teamwork contribute to higher job satisfaction in the Pakistani work environment. Indeed, organizations are always charged with the responsibility of meeting the needs of clients or customers and this can only be feasible with a robust work force. A workforce that is empowered in terms of training and development will create the magic to enhance organizational productivity and employee job satisfaction. Since the relations between these variables are statistically significant, efforts to enhance work empowerment, training, and teamwork should be enhanced. In Pakistan, managers should take note of the findings of this study, and to actively develop strategies in their organizations that foster employee satisfaction for productivity. These conclusions would be helpful to the stability of an organization's personnel in Pakistan and Pakistani employees' occupations.

\section{ACKNOWLEDGMENT}

Authors are grateful to the companies for providing the data for current study.

\section{REFERENCES}

[1] O. M. Karatepe, "Perceived organizational support, career satisfaction, and performance outcomes: a study of hotel employees in Cameroon," International Journal of Contemporary Hospitality Management, vol. 24, no. 5, pp. 735-752, 2012.

[2] P. Paillé, "Perceived stressful work, citizenship behaviour and intention to leave the organization in a high turnover environment: Examining the mediating role of job satisfaction,” Journal of Management Research, vol. 3, no. 1, pp. 1, 2011.

[3] S. Aydogdu, and B. Asikgil, "An empirical study of the relationship among job satisfaction, organizational commitment and turnover intention,” International Review of Management and Marketing, vol. 1, no. 3, pp. 43, 2011.

[4] F. Mohammed, and M. Eleswed, "Job satisfaction and organizational commitment: A correlational study in Bahrain,” 2013.

[5] D. Bakotic, and T. Babic, "Relationship between working conditions and job satisfaction: The case of croatian shipbuilding company," International Journal of Business and Social Science, vol. 4, no. 2, 2013.

[6] J. T. Jessen, "Job satisfaction and social rewards in the social services," Journal of comparative social work, vol. 5, no. 1, 2015. 
[7] P. E. Spector, Job satisfaction: Application, assessment, causes, and consequences: Sage publications, 1997.

[8] W. M. Costen, and J. Salazar, “The impact of training and development on employee job satisfaction, loyalty, and intent to stay in the lodging industry,” Journal of Human Resources in Hospitality \& Tourism, vol. 10, no. 3, pp. 273-284, 2011.

[9] N. A. Bowling, "Is the job satisfaction-job performance relationship spurious? A meta-analytic examination,” Journal of Vocational Behavior, vol. 71, no. 2, pp. 167-185, 2007.

[10] A. Furnham, A. Eracleous, and T. Chamorro-Premuzic, "Personality, motivation and job satisfaction: Hertzberg meets the Big Five,” Journal of managerial Psychology, vol. 24, no. 8, pp. 765-779, 2009.

[11] A. A. Elnaga, and A. Imran, "The Impact of Employee Empowerment on Job Satisfaction Theoretical Study," American Journal of Research Communication, vol. 2, no. 1, pp. 13-26, 2014.

[12] L.-C. Chang, C.-H. Shih, and S.-M. Lin, "The mediating role of psychological empowerment on job satisfaction and organizational commitment for school health nurses: A cross-sectional questionnaire survey,” International Journal of Nursing Studies, vol. 47, no. 4, pp. 427-433, 2010.

[13] H. Raza, J. Mahmood, M. Owais et al., "Impact of employee empowerment on job satisfaction of employees in corporate banking sector employees of Pakistan,” Journal of Applied Environmental and Biological Sciences, vol. 5, no. 2, pp. 1-7, 2015.

[14] R. E. Ripley, and M. J. Ripley, "Empowerment, the cornerstone of quality: empowering management in innovative organizations in the 1990s,” Management decision, vol. 30, no. 4, 1992.

[15] B. L. Kirkman, and B. Rosen, "Beyond self-management: Antecedents and consequences of team empowerment," Academy of management Journal, vol. 42, no. 1, pp. 58-74, 1999.

[16] S. M. Diab, and M. T. Ajlouni, "The influence of training on employee's performance, organizational commitment, and quality of medical services at Jordanian private hospitals," International Journal of Business and Management, vol. 10, no. 2, pp. 117, 2015.

[17] A. Eaglen, C. Lashley, and R. Thomas, "Modelling the benefits of training to business performance in leisure retailing," Strategic Change, vol. 9, no. 5, pp. 311, 2000.

[18] S. C. Bushardt, C. Fretwell, and P. Byrd Cumbest, "Continuous improvement through employee training: a case example from the financial services industry,” The Learning Organization, vol. 1, no. 1, pp 11-16, 1994.

[19] C.-F. Chiang, K.-J. Back, and D. D. Canter, "The impact of employee training on job satisfaction and intention to stay in the hotel industry," Journal of Human Resources in Hospitality \& Tourism, vol. 4, no. 2, pp. 99-118, 2005.

[20] K. Leppel, E. Brucker, and J. Cochran, “The importance of job training to job satisfaction of older workers,” Journal of aging \& social policy, vol. 24, no. 1, pp. 62-76, 2012.

[21] M. N. Khuong, and B. D. Tien, "Factors influencing employee loyalty directly and indirectly through job satisfaction-A study of banking sector in Ho Chi Minh City,” International Journal of current research and academic review, vol. 1, no. 4, pp. 81-95, 2013.

[22] B. A. April, "The impact of training on employee performance: A Case Study of HFC Bank (GHANA) Ltd,” Bachelor Thesis, Ashesi University College, 2010.

[23] M. Adesola, K. Oyeniyi, and M. Adeyemi, "Empirical study of the relationship between staff training and job satisfaction among Nigerian Banks employees," International Journal of Academic Research in Economics and Management Sciences, vol. 2, no. 6, pp. 108, 2013.

[24] J. A. Tarasco, and N. A. Damato, "Build a better career path: Your future depends on how well you cultivate your staff," Journal of Accountancy, vol. 201, no. 5, pp. 37, 2006.

[25] D. Chukwudi, "The impact of teamwork on organizational productivity. Retrieved on 6 October, 2014 from: http://nairaproject.com/projects/522.html,” 2014.

[26] L. S. Hartenian, "Team member acquisition of team knowledge, skills, and abilities,” Team Performance Management: An International Journal, vol. 9, no. 1/2, pp. 23-30, 2003.
[27] A. Jones, B. Richard, D. Paul et al., "Effectiveness of teambuilding in organization,” Journal of management, vol. 5, no. 3, pp. 35-37, 2007.

[28] F. Z. Abdullah, and L. B. Farah, "Personality Profile of F\&B Staff in Malaysia,” Australian Journal of Business and Management Research, vol. 1, no. 9, pp. 24, 2011.

[29] C. Mafini, and D. R. Pooe, "The relationship between employee satisfaction and organisational performance: Evidence from a South African government department,” SA Journal of industrial Psychology, vol. 39, no. 1, pp. 00-00, 2013.

[30] A. B. Nickerson, and R. J. Nagle, "Parent and peer attachment in late childhood and early adolescence," The Journal of Early Adolescence, vol. 25, no. 2, pp. 223-249, 2005.

[31] H. Musriha, "Influence of teamwork, environment on job satisfaction and job performance of the cigarette rollers at clove cigarette factories in East Java, Indonesia,” Developing Country Studies, vol. 3, no. 2, 2013.

[32] L. Men, "Measuring the impact of leadership style and employee empowerment on perceived organization reputation," University of Miami, Submitted to the Institute of Public Relations, 2010.

[33] S. W. Schmidt, "The Job Training and Job Satisfaction Survey Technical Manual,” Online Submission, 2004.

[34] C. Shanahan, C. Best, M. Finch et al., Measurement of the behavioural, cognitive, and motivational factors underlying team performance, DTIC Document, 2007.

[35] P. S. U. Sabri, M. Ilyas, and Z. Amjad, "Organizational culture and its impact on the job satisfaction of the University teachers of Lahore," International Journal of Business and Social Science, vol. 2, no. 24, 2011.

[36] J. F. Hair, M. Sarstedt, C. M. Ringle et al., "An assessment of the use of partial least squares structural equation modeling in marketing research," Journal of the Academy of marketing Science, vol. 40, no. 3, pp. 414433, 2012.

[37] U. Sekaran, and R. Bougie, "Theoretical framework In theoretical framework and hypothesis development," Research Methods for Business: A Skill Building Approach, United Kingdom: Wiley, pp. 80, 2010.

[38] J. F. Hair, W. C. Black, B. J. Babin et al., "Multivariate Data Analysis, Pearson Prentice Hall,” Upper Saddle River, NJ, 2006.

[39] W. W. Chin, and P. A. Todd, "On the use, usefulness, and ease of use of structural equation modeling in MIS research: a note of caution,” MIS quarterly, pp. 237-246, 1995.

[40] V. Ghasemi, "Structural equation modeling in social researches using amos graphics,” Tehran: JameeShenasan Publications (in Persian), 2010.

[41] D. H. Rezaie, P. A. Saleh, A. M. Iman et al., "An analysis of the empowerment level of employees and it's relation to organizational factors,” International Journal of Business and Social Science, vol. 3, no. 15, 2012.

[42] S. A. Carless, "Does psychological empowerment mediate the relationship between psychological climate and job satisfaction?," Journal of Business and Psychology, vol. 18, no. 4, pp. 405-425, 2004.

[43] S. L. Baker, J. J. Fitzpatrick, and M. Q. Griffin, "Empowerment and job satisfaction in associate degree nurse educators," Nursing Education Perspectives, vol. 32, no. 4, pp. 234-239, 2011.

[44] C. Baruch-Feldman, E. Brondolo, D. Ben-Dayan et al., "Sources of social support and burnout, job satisfaction, and productivity,” Journal of occupational health psychology, vol. 7, no. 1, pp. 84, 2002.

[45] A. Seers, G. W. McGee, T. T. Serey et al., "The interaction of job stress and social support: A strong inference investigation,” Academy of management Journal, vol. 26, no. 2, pp. 273-284, 1983.

[46] S. Choo, and C. Bowley, "Using training and development to affect job satisfaction within franchising," Journal of Small Business and Enterprise Development, vol. 14, no. 2, pp. 339-352, 2007.

[47] S. Gazioglu, and A. Tansel, "Job satisfaction: Work environment and relations with managers in Great Britain. Ankara," Middle-East Technical University, 2002.

[48] R. Van Dick, O. Christ, J. Stellmacher et al., "Should I stay or should I go? Explaining turnover intentions with organizational identification and job satisfaction,” British Journal of Management, vol. 15, no. 4, pp. 351360, 2004. 